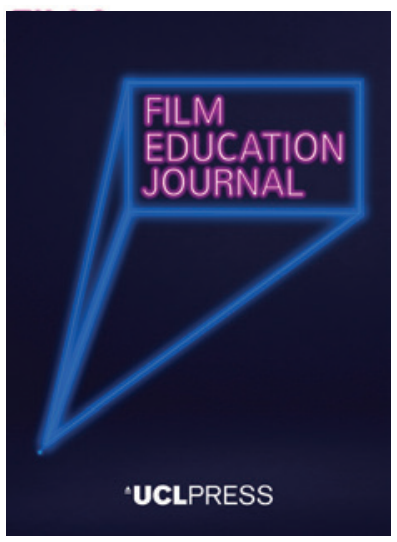

UCLPRESS

FILM EDUCATION JOURNAL

ISSN 2515-7086 (Online)

Journal homepage:

https://www.uclpress.co.uk/pages/film-education-journal

\title{
Film(making) education for all? British cultural policy and film education
}

\section{Chris Nunn (D)}

\section{How to cite this article}

Nunn, C. (2020) 'Film(making) education for all? British cultural policy and film education'. Film Education Journal, 3 (2), 191-205. Online. https://doi.org/10.14324/ FEJ.03.2.06

Submission date: 12 March 2019

Acceptance date: 12 May 2020

Publication date: 26 November 2020

\section{Peer review}

This article has been peer-reviewed through the journal's standard double-blind peer review, where both the reviewers and authors are anonymized during review.

\section{Copyright}

(C) 2020 Nunn. This is an open-access article distributed under the terms of the Creative Commons Attribution Licence (CC BY) 4.0 https://creativecommons.org/licenses/by/4.0/, which permits unrestricted use, distribution and reproduction in any medium, provided the original author and source are credited.

\section{Open access}

The Film Education Journal is a peer-reviewed open-access journal. 


\title{
Film(making) education for all? British cultural policy and film education
}

\author{
Chris Nunn* - University of Greenwich, UK
}

\begin{abstract}
Since the late 1990s various consortia have published papers and reports seeking to establish a systemic public film education in Britain. Despite the time and effort taken by colleagues in organizations such as the British Film Institute (BFI), who have been involved in the production of these papers since at least Making Movies Matter in 1999, it is observable that each policy initiative has eventually fallen away. This article seeks to explore the discourse that these reports, taken together, present and how this might impact the development of a future public film pedagogy, as well as affect students who seek to study film and television production at later stages. This research was finalized shortly before the COVID-19 pandemic, at a time when the film and television industries in Britain were demonstrating huge fiscal successes; however, the fate of the talent that will shape the future of these industries is still very much hanging in the balance.
\end{abstract}

Keywords: British, pedagogy, filmmaking, public, education

During the course of my PhD thesis, 'Towards a new film pedagogy', researching undergraduate filmmaking pedagogy (Nunn, 2018), it became necessary to investigate what experiences of film or filmmaking education students might have had prior to commencing university. The discourse of earlier educational structures, as well as any additional offerings from public sector organizations like the British Film Institute $(\mathrm{BFI})$, undoubtedly has some effect on how students perceive the film and television industries, their future career trajectories and, subsequently, how they choose to quantify their educational experiences. If pedagogic design in higher education is to deliver the best possible outcomes for a diverse range of students, then it is imperative that public models of education are analysed and understood. Better still, a core aim of this article is to suggest that more integration, collaboration and dialogue are needed across all sectors in British education, in order to develop and deliver an effective film education model at all stages.

It is important to note that in my prior role as festival director of Screentest: The National Student Film Festival, the UK's longest-running celebration of student-made films, I enjoyed strong working relationships and support from staff at the BFI, British Academy of Film and Television Arts (BAFTA) and the regional hub Film London. The critique that follows is not therefore designed to denigrate the excellent work done by colleagues in these and other institutions, but instead seeks to provoke some thought and debate as to how a public film education model is (or is not) delivered in a systemic fashion with collaboration from all necessary parties. The history of BFI authored, or co-authored, policy documents is evidence of the ways in which this kind of collaboration, however essential, is very difficult to achieve. 
This investigation is occurring at a time when the creative industries in Britain, particularly film and television, have become a focal point for government and policymakers as their net contribution to the Treasury is being recognized. This was quantified by the 'Independent review of the creative industries':

The Creative Industries are a success story, playing a key role in the UK's economic recovery. They contributed f87.4bn in GVA in 2015, 5.3\% of the UK economy (comparable to the Construction or Information sectors) and between 2010 and 2015 grew by 34\% - faster than any other sector. (Bazalgette, 2017: 11)

Specifically, the film and television industries in Britain are also demonstrating fiscal success, representing $\mathrm{f} 1.4$ billion gross value added (GVA) or 'a total economic contribution of $£ 3.7 \mathrm{bn}$ when supply chains and spillover effects are accounted for' (BFI, 2017b: 10). The BFI Plan 2017-2022 also notes that 'between 2009 and 2013, employment in the core UK film sector grew 21.6 per cent' (BFI, 2017a: 13), far outstripping the wider economy's increase of 3 per cent. While economic contributions and jobs are undoubtedly positive developments, they also require policy intervention in order to develop, and some of these policies have to engage with education and the next generation of would-be film or television makers.

Creative economy aside, there is a rich history of reports of a different nature, designed to address whatever issues have been current in film education and foster links among public institutions, government and the private film industries. These have largely been produced by the $\mathrm{BFI}$, often in collaboration with a range of other institutions. Bolas (2009: 32) posits that the BFI's earliest entries into discussions about film education in schools were in the mid-1930s when 'the Board [of Education] had been lobbied by the BFI on several issues and was becoming more receptive to approaches to film'. More recent reports produced in association with the BFI have been designed to have a similar effect, seeking to mediate between policymakers and the film and television industries. This article will analyse a contemporary selection of these reports, starting with Making Movies Matter (MMM; Film Education Working Group, 1999), continuing with Film: A 21st century literacy (21C; UK Film Council, 2008) and the more recent collaborative effort Future Film Skills: An action plan (BFI, 2017b). Also considered are the critical follow-ups to the first two reports: Making Movies Matter: Seven years on (MMM7; Bazalgette, 2006) and Film: A 21st century literacy re/ defining film education (Available Light Advisory, 2013), in which can be found more critical voices seeking to appraise the impact of the original policy initiatives.

Some confusion around each of these policy publications is caused by the typical life cycle of such a document. A group of stakeholders gather to produce a report, present it and then disappear before any concrete action can take place. It is argued in this article that a lack of guiding cultural policy in the area of film education (and creative education more broadly) has thus hampered any serious changes or responses from taking place, particularly around issues of diversity and participation in the creative industries. This is something the BFI Plan 2017-2022 also expresses concern over (BFI, 2017a: 12). After presenting the individual reports, the second half of this article will reflect on what they might tell us about the involvement of cultural institutions like the BFI in forging film education policy. Finally, I conclude with examples of less high-profile but more effective policy interventions in the UK, with the intention of avoiding some of the pitfalls of the collection of well-meaning but rarely effectual statements of intent that characterize the collaborative reports analysed here. 


\section{History repeating: The problematic case of public film education in Britain}

Looking back at the history of BFI-authored reports into public film education is a telling process. The focus of these reports since 1999 is broad public access to film education. Broad public access manifests in different ways, and the reports in recent iterations note this includes access to practice. The consistent argument put forward in this collection of reports is that every child requires a moving image education to both comprehend and, especially, participate in twenty-first-century culture, and as such it is a laudable mission. How far this goes, how specialized such an education is and whether such an education should involve exposure to, and critique of, the medium as a viewer or also include practice, are the issues that need to be explored.

Garnham (1990: 65), writing nearly a decade earlier than the first of the reports looked at in this section, issued a warning about this so-called 'democratising': 'I believe average citizens to be healthily realistic about this ... Everyone is not, does not want to be and indeed should not be a skilled film-maker, TV producer, or, indeed, animateur. Most people have better things to do.' Of course, in the intervening decades, it has now become part of society writ large for many people, particularly young people, to be avid consumers and producers of moving image media. Visually driven platforms like Instagram, Snapchat and TikTok serve as examples of regular image making by the public. However, video platforms like YouTube and Vimeo also attest to an increased appetite for amateur moving image work, though these platforms encompass a huge variety of forms that may not fit comfortably into the category of 'film'.

Many people in Britain now carry with them a device more powerful than most broadcast cameras available in 1990. This raises the question of how specialist a public model of film education should be. If many people are already producing moving image content, what do they stand to gain from attending workshops with the BFI? The answer to this question, viewed through the history of the BFI's own reports, would be that their models of education, including the current offering in association with Into Film, are about film and the wider screen industries. Here young people are exposed to more specialist aspects of the medium but also to potential career prospects. Yet there is an identifiable dissonance similar to one experienced by film educators in higher and further educational institutions: do we educate because we want young people to experiment with the medium of film, using it to participate in and represent contemporary society, or do we focus educational measures on employability skills, so that young people can be put to work in the industry? It is possible that, much like other areas of neoliberal economies, education at all levels reflects what Fisher (2009: 17) calls a 'business ontology' in which it is 'simply obvious that everything, from healthcare to education, should be run as a business' (original emphasis). Here, the value attached to education in film can only be understood as economic value. To situate the screen industry within a recognizable sphere of value and influence within neoliberal economies is thus necessarily to situate it within a 'business ontology', whereby employability skills are promised so that the industry may continue to recruit the necessary workers it needs to continue to achieve the growth and economic impact along this ontological axis, and organizations like the BFI can claim to directly contribute to the economic well-being of the country, as evidenced through ontologically validated measures such as GVA and GDP (gross domestic product).

It should be noted that the BFI is not solely responsible for the papers discussed here. MMM (1999) and 21C (2008) were both produced by a consortium of film and cultural organizations, including the Arts Council, the British Broadcasting Corporation 
(BBC) and the now dissolved UK Film Council. MMM also comes shortly after A Bigger Picture, published by the Film Policy Review Group in 1998. The earlier report focused more on film industry and production policy and was commissioned by the then Labour Government. The need for a focused report on education exemplifies how crucial this was considered to be in fostering a future interest in filmmaking and the film industry.

While much has changed since MMM was published, some of the issues appear to be the same: 'Moving image education in the UK has developed in random and piecemeal ways for 50 years. This report proposes consistent standards of UK-wide moving image education, accessible to everyone' (Film Education Working Group, 1999: 2). The authors continue:

What we have attempted to do in this report is to hold to the fundamental principle that film is more than an industry, more than a collection of commodities, more than a vehicle for stars and stories. (ibid.: 7)

To enact this laudable aim, the authors of MMM note four key areas for development: 'Analytical Competence', 'Contextual Knowledge', 'Canonical Knowledge' and 'Production Competence' (ibid.: 31). Even as early as the late 1990s, before the digital revolution had properly begun, emphasis in educational policy documents was being placed on the need for a broad film education to involve practice.

As more contemporary reports indicate, the focus on filmmaking practice in public approaches to film education has continued to grow. $21 \mathrm{C}$ makes a distinct plea to recognize the importance of young people engaging with filmmaking practice: 'We live in an age when to be literate means to be as familiar with images on a screen as with text on a page and to be as confident with a camera or a keyboard as with a pen' (UK Film Council, 2008: 6). Crucially, the authors go on to note that: 'film education in the UK remains disconnected and inconsistent - a bonus for some lucky children and young people rather than an opportunity and entitlement for all' (ibid.) Like the reports before it, $21 \mathrm{C}$ was advocating a film education strategy because there was none. The authors listed among current challenges: film education being marginalized, little professional development existing for teachers and no agreed existing pedagogic approaches for film education (ibid.: 10); whether these challenges remain in place over a decade later is unclear. It is, however, observable that film and media subject areas are gaining more recognition from government and policymakers, as the creative industries are clearly demonstrating their economic contribution. $21 \mathrm{C}$ summarizes four key aims: to devise a professional development programme for teachers, to develop online resources for the UK screen archives to accompany every publicly funded British film, to build a network of schools' film clubs and to pilot 'a new kind of partnership between the film and education sectors' (ibid.: 16). An organization like FILMCLUB, which ran after-school screening sessions in schools nationwide, had successfully created such a network, which has now been absorbed by Into Film, the BFI's current education partner.

While the papers discussed here advocate for collective action, some incongruences appear when analysed. One such example is in the formation of Into Film in 2013 as a merger between FILMCLUB, who focused more on screenings and talks in schools, and First Light, who funded youth digital filmmaking workshops with collaborating organizations nationwide. Left out of this merger was Film Education, formed in 1985 and successfully running 'National Schools Film Week' with 541,744 young people attending screenings in 2012 (BFI, 2017c: 186). From the data presented it is clear that by closing Film Education and rebranding the event first 'National Youth Film Festival' (BFl, 2014b: 172) and then 'Into Film Festival', the number of children 
attending dropped dramatically to 246,434 (less than half) and only built back up to 371,164 in 2018 (BFI, 2019: 204). What happens when organizational shifts damage the long-term work that has already been done? Each report discussed here presents a similar case, not of building on what the last paper argued or looking at the legacy of the recommendations, but instead starting afresh each time, as if the previous work was irrelevant to the current context. This is certainly the case in the nine years between MMM and 21C, where the latter entirely fails to mention its predecessor. While the BFI's film education strategy, Impact, Relevance and Excellence: A new stage for film education (BFI, 2014c), does make mention of both reports, the more recent Future Film Skills (BFl, 2017b) does not.

When the BFI became the sole distributor of public film funding in Britain after the dissolution of the UK Film Council in 2012, it was clear that its educational department saw merit in the models its historical co-authored reports had been championing. Subsequent papers composed solely by the BFI continued to advocate for a model of public film education that encompasses making as well as appreciation; indeed, the making of film is considered a key part of this appreciation. More recent reports, like the BFI's film education strategy, Impact, Relevance and Excellence (2014c) or the pan-European document (produced by a consortium led by the BFI) A Framework for Film Education (BFl, 2015b), are examples. The former notes in its opening that 'we are concerned with learning about film, learning through film and also learning about - and engaging with - film as a vocation' (BFI, 2014c: 3, original emphasis). The latter, though it had no direct impact on policy in the UK, makes a strong case for film practice acknowledging that:

The advent of digital filmmaking has led to the possibility of viewers becoming makers. The links between these two experiences - using viewing as a way into making and then evaluating the viewing of the creation need to be explored. Film education is thus about developing not only a culture of informed, critical film viewing but also a culture of filmmaking, on the basis that criticality and creativity are interrelated. (BFI, 2015b: 9)

It is a necessary development to note here the interrelation between the viewing and subsequent making of films. The lingering question is the extent to which the policies that reports like this intend to provoke ever achieve the desired level of criticality or policy support. If at least a part of the focus reflects an 'industrial imperative', to use Petrie and Stoneman's (2014: 42) term, then to what extent can that industry be brought into view critically?

It is important to note at this stage the differences in the types of papers and reports being discussed here. Chiefly, there are those that are sole products of institutions like the BFI and those that are collaborative. The extra weight behind collaborative reports like MMM and $21 \mathrm{C}$ might help in garnering more recognition for the paper at time of publication and perhaps in promoting the recommended action points. Of note, however, is the fact that each report was followed up by a subsequent one looking into the impact and legacy of the originals. In these publications more critical voices are found, often noting the shortcomings of the original papers and failure to action of many of the points raised.

MMM7 (Bazalgette, 2006) is the first of the follow-ups and speaks to the failure of the initial report to gain much ground. Authored by former BFI head of education Cary Bazalgette, MMM7 begins by indicating that the initial report was looking to establish a systemic film education and saw that part of that would have to involve 
collaboration with the film and television industries. Unfortunately, 'after the report's publication, neither the DCMS [Department for Culture, Media \& Sport], nor the BFI and UK Film Council senior managements, undertook any high-level engagement on the MMM proposals' (Bazalgette, 2006: 1). Talking of the difficulties of putting some of MMM's recommendations into action, Bazalgette remarks on the 'uncoordinated efforts' that hinder action: 'so many of MMM's proposals ... were left to agencies at operational, rather than policy, level, (BFI Education, Film Education, venues and film societies) each subject to conflicting and rapidly changing policy demands' (ibid.: 4). Other proposals were hindered when the UK Film Council began to coordinate its own efforts, without consultation with other bodies. As a case study, MMM provides an example of the difficulties of coordinated action with publicly funded bodies, and it shows that the conflicting, constantly shifting, demands made by these organizations cannot be conducive towards an agreed approach to filmmaking pedagogy. This is further demonstrated when we consider that the UK Film Council and Film Education, who also contributed to $21 \mathrm{C}$, are both organizations that no longer exist, being dissolved in 2012 and 2013 respectively. Bazalgette is forced to conclude, as alluded to earlier in this article, that change in education cannot come quickly and cannot always come from the 'high-level advocacy' (ibid.: 5) engendered by collaborative papers like MMM. In the end, 'although high profile initiatives may contribute to opinion-forming, they do not by themselves achieve sustainable change' (ibid.). If these reports are to contribute to educational initiatives, more work needs to be done to encourage and actualize their recommendations with the groups that would actually have to deliver them. This conversation needs to broaden and include not just the agencies responsible for policy but also teachers and academics who will need to enact and engage with a public model of film education in their more formal settings. This would constitute the systemic approach that has been encouraged for many years without yet being fully realized.

The second follow-up report, Film: A 21st century literacy re/defining film education (Available Light Advisory, 2013), involved a wider circle of contributors and comes closer to Bazalgette's collaborative vision. This paper is a verbatim transcript of a seminar held at the BFI in London, consisting of film education professionals, this time including some teachers and academics. The discussion here is much more realistic, noting where shortcomings in current approaches to film education can be found. 'There is a need to acknowledge that if we' $d$ been here five years ago, we' $d$ be having the same discussions as today - this is not a negative comment, but it reflects a situation that exists at the moment' (Available Light Advisory, 2013: 16). According to the attendees of the seminar, the real challenge in contemporary film education lies in defining exactly what it is. The delegates here commented on the difficulty in film of a balance between theory and practice (ibid.: 13), the necessity of distinguishing film as a subject (ibid.: 12), utilizing its unique aspects to dispel the 'soft option' stigma, and the difficulties of coordinating this in a climate of limited time, limited funds and a host of different providers, each with their own aims. 'The breadth of the issue has become really apparent, with the complexity and demands of different providers coming at it from so many angles making it harder to pinpoint an exact definition of film education' (ibid.: 17).

In a climate that demands continual justification of investment, it is quite difficult to admit these complexities and this is perhaps why so many reports and policy documents enter base dialogues designed to please a specific readership. One example of policy simplification that was repeated in multiple arenas was the concept of the 'three Cs': cultural, critical and creative. The first appearance of the 'three Cs' 
concept was developed by another failed high-advocacy policy initiative, the Charter for Media Literacy (2005). Part of a wider European project, 'the Media Literacy Task Force' coalition comprised 'the UK Film Council, the British Film Institute, the BBC and Channel 4' (Bachmair and Bazalgette, 2007: 83). Despite having little impact on policymakers, perhaps most exemplified by the UK Government's attack on the media studies A level in 2015, the wider European initiative that was published online in 2006 is still currently gathering signatories (http://euromedialiteracy.eu/). One example of a clear lack of impact on policy are comments from then Minister of Education Nicky Morgan when her department tried to discontinue the media studies A level. Launching a campaign that promoted STEM (science, technology, engineering and mathematics) subjects in 2014, Morgan stated that 'If you didn't know what you wanted to do ... then the arts and the humanities were what you chose because they were useful, we were told, for all kinds of jobs.' She concluded that 'We now know that this couldn't be further from the truth' (Paton, 2014).

To note one example of the Re/Defining Film Education group's dedication to acknowledging the difficulties in creative education, they develop the 'three Cs' from the Charter, also cited in 21C, and expand them to 'eight Cs' that need to be looked at when defining film education. They add context and connectivity, collaboration, careers and curiosity. What this expansion of the $\mathrm{Cs}$ does is widen not only the potential of film as a medium but also the importance of it to the education of young people. Educational models that foreground the industrial aspects of filmmaking are at best addressing 'career' and perhaps 'context' but are leaving out many of the other facets of film education, and educators cannot hope students will comprehend the medium if they are only exposed to narrow fields of it. It is possible to trace the influence of the one-day symposium when Impact, Relevance and Excellence (BFI, 2014c) is analysed. This film education strategy document opens with a remark that speaks more to the complexity of public film education and what must be done to move forward:

One challenge is how to describe and promote this body of activity which is so vital for how we learn, shape and communicate our ideas and culture in the 21 st century. Reframing what we mean by film education will help us all towards a more meaningful description. (Ibid.: 3 )

Some suggestions for this reframing came from the seminar, though it is not clear where this influence can be located in later documents. While the comments of those attending Re/Defining Film Education, including academic Terry Bolas and the chief executives of First Light and FILMCLUB, are welcome additions to the discourse of film educational reports in Britain, it is once again necessary to consider whether any real change can be seen in the years since its publication.

The assumptions of the BFI's (2017b) report Future Film Skills: An action plan posit the answers to the question posed above as 'no'. The history of enquiry into film education runs the risk of repeating itself, with a new agenda being published to eclipse whatever has come before, including the refreshing and honest comments in Film: A 21st century literacy re/defining film education (Available Light Advisory, 2013). The Future Film Skills report does speak to some contemporary issues, particularly addressing the increased need for diversity in the film and television industries. Arguably, having this discussion at a high-profile policy level can be a good thing if it leads to real change in industrial attitudes and is not merely further lip service. As with each of the reports discussed, however, there are positive and negative aspects to the intentions of the authors. They note a creeping skills shortage in the expanding UK film and television sectors, fields that are becoming increasingly intertwined. Addressing 
this gap includes dealing with diversity and inclusivity, and the Future Film Skills report includes a concrete 'action plan', which at least reads better than any of the prior evaluations whose conclusions were always couched in terms of 'recommendations'. Several years after its injection of public funds and after replacing the UK Film Council in 2012, it seems that the BFI might be ready to become the key player it has always had potential to be in terms of influencing industry policy.

The actions listed in this plan sound somewhat familiar, however, especially: '2. An accreditation system to guarantee employer confidence' and '7. [Establish] Worldclass centres of excellence for screen-related craft and technical skills' (BFl, 2017b: 26). The report appears to have forgotten, or dismissed as superfluous, the Creative Skillset (now Screenskills) 'tick' for accredited university courses, including three Creative Skillset film academies. Like the papers discussed earlier in this article, it appears that this most recent report is also more interested in wiping the slate clean and starting afresh than in building on what already exists. This is not to say that Creative Skillset approaches are not problematic. Henning Camre, former head of the National Film School Demark and briefly head of the National Film and Television School in Britain, saw them as being emblematic of the shift to a reductive skills-based training. He discusses this in an interview with Petrie and Stoneman: 'I've never heard them talk about content or quality' (2014: 108). It does not look like the current iteration of BFI-led policy, itself titled 'Future Film Skills', is planning to expand film education to include aspects that do not have direct links to future industry employment. Whether the now rebranded Screenskills is providing accreditation or not, Camre's criticism still stands and this once again foregrounds the need for a discussion about the philosophy and approach of public film education policy.

The authors of Future Film Skills take some time to note why it was important for them to present their recommendations here as an 'action plan': 'At every stage, from inspiring young people to improving existing skills, the success of this plan depends on our full involvement as an industry and a creative sector' (BFI, 2017b: 23). As with the reports that have come before it, the aims here are to foster some collaboration between policymakers and the industry. The importance of this is stressed by the concluding action: '10. Mobilise the industry: Everyone in the industry needs to get involved. Whether it's through offering speakers, time to coach, or one-to-one meetings, or mentoring - we all need to commit some of our time to inspire the next generation of workers' (ibid.: 27). While this call to arms is admirable, the existence of similar rallying cries in prior policy documents leads one to conclude it may again fall on deaf ears.

The role of public film education presented here is a very specific example within the British context and these findings are not necessarily generalizable beyond that. This case study does, however, raise several considerations that may find resonance with colleagues in other countries. I will now go on to analyse and discuss some of the issues raised by the reports mentioned, moving towards a conclusion that seeks to question the function of such high-level advocacy reports and how necessary they are in achieving lasting change in education at ground level.

\section{Breaking down the discourse of public film education reports}

As outlined, there are several issues apparent in each of the papers mentioned. These problems are intensified when the reports are taken together as representing the conversations that have taken place at policy level since the late 1990s. Two problems in 
particular are considered here. First is the need for film education to carve out its own space as an area of learning and not one that rests purely on its potential to contribute to economic growth. This means a direct move away from the instrumentalization of filmmaking that is increasingly prevalent in the papers presented. The second issue is the relationship between public film education policy and the film and television industries.

The BFI has, as evidenced by its own policy documents, taken on the duty of tackling the lack of diversity in the film and television industries. This can be seen as early as in its Royal Charter, originally written in 1983 but revised most recently in 2015. The authors note among their aims that the BFI exists 'to promote access to and appreciation of the widest possible range of British and world cinema' (BFI, 2015a: 3). The need to promote diversity in the film and television industries was also championed by the BFI's 'three ticks' funding scheme, also rolled out in 2015. The original press release announcing the scheme states that:

The three ticks assessment requires applicants to demonstrate commitment to diversity across three areas of their production, ranging from the make up of the workforce to the stories and characters on screen, with at least one tick needed in a minimum of two areas for a project to be eligible for BFI production funding. (BFI, 2014b: 4)

These aims are more difficult if the public film education model primarily focuses on mainstream cinema and the glamour of the Hollywood and British film industries. Lip service is consistently paid to the need to foster diversity in film, no more so than in the 2017 report Future Film Skills. This is, however, incompatible with the celebration and lionization of current film and television outputs that have consistently failed to incorporate diversity into their working environments or programming. The tensions here need to be addressed.

For example, one of the opening comments of $21 \mathrm{C}$ reads: '[Film education] enables children and young people to use film as a vehicle for their own creativity, and encourages the film industry to respect their voices' (UK Film Council, 2008: 4). This statement is palpably false: at no stage in any of the reports produced by the BFI or associated organizations has anyone provided an example of the industry respecting young people's voices. Even if industry did respect their voices, low to no wage entrylevel jobs demonstrate the recurring barriers for young people and would-be industry entrants. The idea that the $\mathrm{BFI}$ continues to propagate this notion is problematic at best. A brief glance at the signatures at the top of $21 \mathrm{C}$ gives an indication as to why the image of the film industry painted here is so rosy: Stewart Till (UK Film Council, film producer), Greg Dyke (BFI, former chairman of the BBC) and Barbara Broccoli (First Light Movies, film producer). This report, along with the others discussed, seems designed to make both policymakers and industry feel comfortable, safe in the knowledge that, despite signing a report that was a clamour for reform, they were signing a document that really tells readers that everything is okay: the film industry is respectful of young people.

Similar issues abound in the 2017 report Future Film Skills. The top of the document lists the members of the BFI's 'Film Industry Task Force' (BFI, 2017b: 6) and the title itself tells us who we can expect to see on this list. The BFI and Creative Skillset are obviously returning members, as is Barbara Broccoli, this time representing her production company EON. Added to this most recent document are other production or post-production companies, including Double Negative and Big Talk Productions, as well as people such as lain Smith of the Film Skills Council. Like the reports before it, this also appears to be an example of high-level advocacy. The inclusion of production companies is no doubt an attempt to address problems raised in previous reports. However, missing entirely from 
this list of contributors are educators, despite the report taking time to focus on where film and television industry entrants are being developed (ibid.: 15-16).

Again this means that the conversation, action points and policy recommendations that follow are not being discussed with those who will have to consider this in an educational setting. The discourse of film education reports needs to make a shift towards two aims. One is to develop a public film pedagogy that encourages diverse viewing habits. This has been mentioned in every report since MMM but is notably missing in Future Film Skills. Public film education policy has changed during the two decades of reports from the late 1990s, from advocating some elements of practice alongside wider film appreciation to instead tailoring itself solely to practice and only in the sense that this can lead to future careers in the film and television industries. As such, the current iteration of policy can be seen as extremely narrow. The second aim is to make a shift away from industrial concerns and towards a broader film education, one that may or may not lead to future vocations. If you bring in members of a 'task force' from production or post-production, then they will obviously tailor policy to ensure they have a future workforce; these members have vested interests that arguably keep them from seeing either a bigger picture or working towards a sustainable future. There is thus no incentive for real change, either from those engineering film policy or from the clearly intended industry readership.

For example, only now that the issues of diversity and representation have become headline news has the policy driver changed to include these, and, again, this is only in terms of high-level advocacy. It is also notable that these discussions always focus on race and gender, with little thought given to class, even though statistics (Creative Skillset, 2014; DCMS, 2015) point to this as an inclusivity issue also. In order to broaden the film viewing and subsequent filmmaking habits of young people in Britain, the already dominant film and television industries need to mute their role in public film education and share the space with others. Teachers in schools or colleges, academics in universities and diversity advocates in non-governmental organizations (NGOs) or small-medium enterprises (SMEs) need a seat at the table in these policy discussions, a seat they have been denied for a large portion of the period that has been analysed here. This would be entirely in the interests of the film and television industries to explore, noting they have only a partial picture of the possibilities.

The policy that drives public film education is key for learners in higher education because their thoughts and feelings about the film industry are partially formed here. There is a need for a critical examination of how the screen industries function, and for closer engagement with those industries to highlight the realities of employment opportunities. Director Paul Greengrass discussed the problem of entry-level jobs in his interview with the Guardian in 2016: 'there's no question that being able to be sustained by your parents when starting salaries are luncheon money and contract length is tiny is invaluable. It's being filled by people with means' (Shoard, 2016). This grim picture is reinforced with recently published television and acting case studies in The Class Ceiling: Why it pays to be privileged (Friedman and Laurison, 2020). If diversity and what Future Film Skills terms 'the great challenge of inclusion' (BFI, 2017b: 18) are really top of the agenda then this requires strong legislation around working hours, much more than the proposed 'mobilis[ing] of the industry'. Greengrass continues: 'We've got to work harder as an industry to make young people's route in benign. It wasn't that I didn't have my arse kicked, but you were in a system where you had time to make mistakes and were given space not to conform' (Shoard, 2016).

Considering the close and conspicuous relationship of the reports mentioned to the film industry, as well as the confusing messages these reports, taken together, 
present, it is clear that more work is required in the thinking and design of public film education in Britain. Certainly, when treating film and television as a career progression route, a more realistic and less celebratory approach is required. Britain is not alone in this issue as Caldwell (2008: 165) notes in discussing the career prospects for young people in Los Angeles: 'If working as a PA was demoralizing, working as a [video] logger is now even worse. At least PAs can hold onto the fantasy that they may someday move up, while loggers never will, even after years spent in videotape logging sweatshops.' Graeber's Bullshit Jobs details how 'managerial feudalism manifests itself in the creative industries through an endless multiplication of intermediary executive ranks' (2018: 181). Any pedagogy that seeks to encourage young people into a future like the one that Caldwell (2008), Graeber (2018) or Friedman and Laurison (2020) outline must be challenged and subsequently rethought.

Before concluding by looking briefly at examples of more effective but less notable policy initiatives, an educational alternative in the work of Steve Goodman and the Educational Video Center (EVC) in New York is worth considering. Goodman (2003) documents his work in Teaching Youth Media: A critical guide to literacy, video production, and social change and presents an example of a pedagogy that puts into practice some of the shortcomings of the approaches already noted. The centre works with disadvantaged youth from inner-city schools, who often have poor academic records and literacy skills. These students are emblematic of several under-represented groups in the film and television industries.

Straightaway it is clear that the impetus of the school is on using film to explore local social issues. This can be seen in some of Goodman's opening statements on the importance of media education, particularly with reference to the urban youth he works with. He notes:

... congruence between two very different systems: the system of global media that wants young people to be spectators and consumers, rather than social actors, and a factory system of schooling that wants young people to be passive and willing vessels for a prescribed set of knowledge and skills. For poor or minority children, a third system is congruent with the first two: a social and political order that wants to monitor and control their behaviour to minimize risks to the white, middle-class community. (Goodman, 2003: 2)

Goodman has clearly recognized something that is not being discussed. Having reviewed a host of public film education reports, we know that this discussion does not take place at policy level in Britain, these documents being in part authored by members of the two systems that Goodman highlights. Petrie and Stoneman (2014: 220) develop this idea, pointing out that historically some film education institutions have been 'shaped outside or even against the industry'. Given that the conversation around public education has been so in favour of industry since the late 1990s, a shift in an alternative direction is required.

Goodman has drawn on the work of Paulo Freire in fostering a 'critical literacy', akin to what educators should be doing, certainly in universities but in wider educational settings also. In his original proposition of 'critical pedagogy', Freire (1996: 28) defines it thus:

This pedagogy makes oppression and its causes objects of reflection by the oppressed, and from that reflection will come their necessary engagement in the struggle for their liberation. And in the struggle this pedagogy will be made and remade. 
Goodman's students are 'the oppressed' here and, by drawing on Freire, he is invoking a powerful method to get these under-represented teenagers to reflect on and question the role that film, television and the broader media industries have to play in their oppression. Freire's pedagogy is also not a fixed notion but something that evolves in collaboration with the students and adapts to local needs.

For Goodman's work at the EVC in after-school or community-learning programmes, and for any public film education model, it is essential that the 'guiding principles are based on a youth empowerment model; that is, as active participants in community problem-solving and as full partners in their own learning and growth' (Goodman, 2003: 103). There is a distinct difference between this approach and the lip service that is paying young people 'respect' in the educational reports analysed. Reflecting on their experiences is the area in which Goodman finds students have the most empowering experiences. As part of screening their work to an audience of family, friends, participants and community leaders, students are also asked to reflect on their film in front of the audience. Asked why they chose to make a film on mainstream media misrepresenting youth, one participant responded:

Because you know, they judge me by who I am, and the way I look. Because if they say youth are useless and they are bad. We can think better than them. And we can be smarter than them by doing this kind of work. By showing this kind of work, it is like we are fighting back for our rights. (Goodman, 2003: 112)

The example of the work at the EVC is presented as a juxtaposition to current trends in the evolution and current iterations of film education policy in Britain. Through Goodman's work, we can see that encouraging diversity is a first step but that the focus of the pedagogy is also crucial. The BFI currently looks to be doing the former but not the latter. The students on Goodman's projects first contextualized the media, then themselves in relation to the media and then produced work directly in response to that. This is a very rare combination that is certainly not advocated for in any of the reports we have analysed. Fostering this kind of thinking and development will only help students on their journey to becoming filmmakers, and in turn help the film and television industries to welcome new, sometimes dissenting, voices, and the innovative content that is subsequently produced.

\section{Are high-level advocacy reports necessary to public film pedagogy design?}

Through the analysis and discussion of reports in this article, it is clear that public education policy around film and filmmaking in Britain is becoming increasingly narrow, exacerbated by some of the troubling vocational and instrumental trends that have also been identified in spaces of higher education. Is it possible that lesser publicized schemes actually produce the results that the high-level advocacy reports claim? If those analysed were seeking a systemic film/making education then one excellent example is A Wider Literacy, produced by the BFI and Northern Ireland Screen in 2004. By justifying filmmaking education as part of a necessary literacy for twentyfirst-century life, much like $21 \mathrm{C}$ was suggesting, the team behind A Wider Literacy were able to successfully create a 'Moving Image Arts' qualification at both GCSE (15-16 year olds) and A level (17-18 year olds), the only curricula of this type in the whole of the UK (see Northern Ireland Screen (2020) for contemporary details of this qualification; also see Media Literacy in Northern Ireland (Kerr, n.d.) for more about its 
establishment). If the reports analysed in this article were serious about an integrated and structured film/making education then involving educators in the discussion with a mind to creating such qualifications would be the first step.

It is also notable that despite educators not being directly involved in the reports analysed, save for the more critical reflection on 21C, they have been involved in recent years in combating politically motivated attacks on media studies A levels in England. Former Education Secretary Michael Gove 'promised [a] bonfire of subjects seen as soft or outside the educational mainstream' (Adams, 2015). Gove made a 'pledge for exams to be "more challenging, more ambitious and more rigorous"' (ibid.) and saw media studies as an example of a subject that did not meet these criteria, one objection being the lack of canonical texts (which the film studies A level does have). However, thanks to a coordinated response of media teachers, academics and the BFI to the Office of Qualifications and Examinations Regulations (Ofqual), media studies survived the cull of subjects that saw leisure studies, anthropology and catering axed.

Finally, despite some of the criticisms levelled here, especially those aimed at the BFI, it is necessary to acknowledge that some lesser-known policy initiatives have made a greater impact in the period covered in this article. The BFl's (2012) 5-19 Film Education Scheme 2013-2017 was a solo effort in the immediate aftermath of the termination of the UK Film Council. This scheme provided funding of $f 7$ million per financial year, for four years, to initiatives that either developed a new digital platform, delivered a film education programme (including watching, understanding or making films) or helped establish the Youth Film Academy Network (BFI, 2012: 2). While perhaps still tied too closely to industry, the BFI Film Academy established as a result of this has still been essential in creating progression routes into work for some of its graduates, at a fair rate of pay. It has also certainly provided opportunities to some who might not otherwise have had them, including several undergraduate students taught by this author.

If the aim of film education contemporarily is to encourage diversity, then it is logical that this has to start with a well-resourced public model. The reach of the $\mathrm{BFI}$ and Into Film's programmes, as well as the range of young people they engage with in Britain, is far greater than university undergraduate programmes ever will be. Furthermore, there needs to be some healthy distance between the design and approach of public film pedagogy and the vested interests of the film and television industries for conservative, culture-replicating experiences that reinforce a notion of the existing practice as desirable. Some intersection will absolutely be necessary; however, as demonstrated by Goodman (2003), this does not have to pander to industry requirements. Perhaps though, as evidenced in the analyses of the case studies outlined here, this work cannot be done by high-level advocacy reports and the readership to which they are tailored. Instead, collaboration by public-funded agencies like the BFI, media/film teachers and academics, as well as those in the industry who are willing to enact changes in working practices, might bring about the desired changes. A more critical public film pedagogy is no doubt within reach in the UK - only we might never read a report about it.

\section{Notes on the contributor}

Chris Nunn is currently programme leader for the BA Film and Television Production at the University of Greenwich. As the former festival director of Screentest: The UK's National Student Film Festival, Chris has been championing aspiring filmmaking talent for nearly a decade. Passionate about filmmaking education, he has recently completed 
his PhD entitled 'Towards a new film pedagogy: Recrafting undergraduate filmmaking education for an expanded field' (2018) and plans to continue and broaden research in this area. He is also currently working on a proposal for a research project on class, creativity and talent in UK film and television, as well as a book on anarchist histories.

\section{References}

Adams, R. (2015) 'Media studies survives - but leisure studies doesn't - in final cull of A-levels'. The Guardian, 26 March. Online. www.theguardian.com/education/2015/mar/26/media-studiessurvives-but-leisure-studies-doesnt-in-final-cull-of-a-levels (accessed 27 March 2018).

Available Light Advisory (2013) Film: A 21st century literacy re/defining film education. London: Film: 21st Century Literacy.

Bachmair, B. and Bazalgette, C. (2007) 'The European Charter for Media Literacy: Meaning and potential'. Comparative and International Education , 2 (1), 80-7. Online. https://doi.org/10.2304/ rcie.2007.2.1.80

Bazalgette, C. (2006) Making Movies Matter: Seven years on. London: BFI.

Bazalgette, P. (2017) 'Independent review of the creative industries'. Department for Digital, Culture, Media \& Sport, 22 September. Online. www.gov.uk/government/publications/ independent-review-of-the-creative-industries (accessed 11 August 2020).

BFI (British Film Institute) (2012) BFI 5-19 Film Education Scheme 2013-2017. London: BFI.

BFI (British Film Institute) (2014a) BFI Obligates and Supports Lottery Funding Recipients to Reflect UK Diversity, Starting with Film Production. London: BFI.

BFI (British Film Institute) (2014b) BFI Statistical Yearbook 2014. London: BFI.

BFI (British Film Institute) (2014c) Impact, Relevance and Excellence: A new stage for film education. London: BFI.

BFI (British Film Institute) (2015a) British Film Institute Royal Charter. London: BFI.

BFI (British Film Institute) (2015b) A Framework for Film Education. London: BFI.

BFI (British Film Institute) (2017a) BFI Plan 2017-2022. London: BFI.

BFI (British Film Institute (2017b) Future Film Skills: An action plan. London: BFI.

BFI (British Film Institute) (2017c) BFI Statistical Yearbook 2017. London: BFI.

BFI (British Film Institute) (2019) BFI Statistical Yearbook 2019. London: BFI.

Bolas, T. (2012) Screen Education: From film appreciation to media studies. 1st ed. Bristol: Intellect Books.

Caldwell, J.T. (2008) Production Culture: Industrial reflexivity and critical practice in film and television. Durham, NC: Duke University Press.

Creative Skillset (2014) 'Workforce survey: 2014'. Online. https://www.screenskills.com/media/1559/ creative_skillset_creative_media_workforce_survey_2014-1.pdf (accessed 2 March 2018).

DCMS (Department for Culture, Media \& Sport) (2015) 'Creative industries: Focus on employment'. Online. www.gov.uk/government/uploads/system/uploads/attachment_data/file/534305/Focus_ on_Employment_revised_040716.pdf (accessed 2 March 2018).

Film Education Working Group (1999) Making Movies Matter. s.l.: Film Education Working Group.

Film Policy Review Group (1998) Film Review Group Report: A bigger picture. s.l.: Film Policy Review Group.

Fisher, M. (2009) Capitalist Realism. London: Zero Books.

Freire, P. (1996) Pedagogy of the Oppressed. London: Penguin Books.

Friedman, S. and Laurison, D. (2020) The Class Ceiling: Why it pays to be privileged. Bristol: Policy Press.

Garnham, N. (1990) Capitalism and Communication (Media Culture \& Society Series). 1st ed. London: SAGE.

Goodman, S. (2003) Teaching Youth Media: A critical guide to literacy, video production and social change. 1st ed. London: Teachers College Press.

Graeber, D. (2018) Bullshit Jobs. London: Allen Lane.

Kerr, A. (n.d.) Media Literacy in Northern Ireland. Belfast: Centre for Media Research, University of Ulster.

Northern Ireland Screen (2020) 'Moving Image Arts'. Online. www.northernirelandscreen.co.uk/ education/moving-image-arts/ (accessed 5 June 2020).

Nunn, C. (2018) 'Towards a new film pedagogy: Recrafting undergraduate filmmaking education for an expanded field'. PhD thesis, University of Greenwich, London. 
Paton, G. (2014) 'Nicky Morgan: Pupils "held back" by overemphasis on arts'. The Telegraph, 10 November. Online. www.telegraph.co.uk/education/educationnews/11221081/Nicky-Morganpupils-held-back-by-overemphasis-on-arts.html (accessed 27 March 2018).

Petrie, D. and Stoneman, R. (2014) Educating Film-Makers: Past, present and future. 1st ed. Bristol: Intellect Books.

Shoard, C. (2016) 'Paul Greengrass: "Young people starting out in film and TV are being screwed to the ground"'. The Guardian, 5 April. Online. www.theguardian.com/film/2016/apr/05/paulgreengrass-young-people-breakthrough-brits-bafta (accessed 15 August 2018).

UK Film Council (2008) Film: A 21st century literacy. London: BFI. 